\title{
Organizing the environmental governance of the rare-earth industry: China's passive revolution
}

\begin{abstract}
The rare-earth industry is of strategic importance for China and many 'clean' technologies worldwide. Yet the processes of mining, smelting and separating rare-earth ores are heavily polluting. Using a neo-Gramscian perspective in the context of organization studies, this article analyzes the dynamic interactions between government agencies, business and civil society in the development of the environmental governance of China's rare-earth industry over the past 30 years, with a particular focus on China's 'top-down' passive revolution. Making use of rarely granted access to China's biggest rare-earth company, one of the country's key strategic assets, the analysis makes visible the changes of environmental contestations amongst five different governance actors over what we identify as three environmental governance eras in China. Besides offering unique empirical insights into the organizational processes that constitute the dynamically evolving hegemony of China's rare-earth industry, the article makes three theoretical contributions to the field of organization studies. First, we analyze the changing role of state institutions in a non-Western context, which has been de-emphasized by existing organization scholars. Second, we conceptualize the dynamics of environmental governance in China as a form of top-down 'passive revolution'. Third, we problematize the dual role of Chinese NGOs as both supporting and challenging state power. Overall, we contribute to our understanding of the organization of governance systems in non-Western contexts, which has been neglected in organizational studies.
\end{abstract}

\section{Keywords}

Environmental governance, neo-Gramscian approach, the state, passive revolution, hegemony, rare-earth industry, civil society

\section{Introduction}

To understand the environmental governance of the strategically important and highly polluting rare-earth industry in China, this article takes a neo-Gramscian approach (Böhm et al., 2008; Girei, 2016; Levy \& Egan, 2003; Levy et al., 
2016; MacKay \& Munro, 2012; Okereke et al., 2009; Wittneben et al., 2012), investigating the changing hegemony building processes amongst Chinese state agencies, businesses and green NGOs over the past 30 years. The most common perception of China is that the state plays a distinct and significant role. Whilst this is undeniable, perhaps less well understood is that state power and the roles of non-state actors have changed significantly in China since the 1990s.

Post-World-War-II capitalism has been organized along different 'logics of economic activities and rules of the game' (Morgan, 2011, p. 14), and government agencies, businesses and NGOs have hence played different roles within the institutional diversity of environmental governance (Levy \& Newell, 2005; Wittneben et al., 2012). Since the 1990s, with the much-discussed shift from government to governance (Rhodes, 2007), multiple conflicts between the state, multinational corporations and communities have arisen due to the often negative social and environmental impacts of industrialization, particularly for the extractive industries (Banerjee, 2017). Neo-Gramscian conceptions have been used widely in organization studies (OS) to investigate organizational struggles among state agencies, businesses and NGOs, with analyses focusing on social movements (Spicer \& Böhm, 2007; Van Bommel \& Spicer, 2011); counter-hegemony (Girei, 2016; MacKay \& Munro, 2012); corporate citizenship (Crouch, 2006; Nyberg et al., 2013); and hegemony and political strategy (Levy \& Scully, 2007; Maielli, 2015). With climate change becoming a serious threat to hegemony (Böhm et al., 2012) - hegemony being understood as a unique alignment and consensus between dominant politicoeconomic groups and the cultural forces of civil society (Gramsci, 1971) - the neo-Gramscian perspective has been introduced in environmental governance research to address the ability of non-state actors to outmaneuver their rivals over environmental contestations and negotiations (Levy \& Egan, 2003; Levy et al., 2016; Levy \& Spicer, 2013; Okereke et al., 2009; Rothenberg \& Levy, 2012).

However, with recent emphases on non-state power in the context of neoliberal governance systems, most neoGramscian studies in OS have focused on Western, Anglo-Saxon contexts. As in OS more generally, neo-Gramscian approaches have tended to neglect or de-emphasize the role of the state in governance relations. This is surprising for two reasons: first, Gramsci himself took the state very seriously, characterizing it as 'hegemony protected by the armour of coercion' and seeing its institutions playing a vital part in the organization of hegemony (Gramsci, 1971, p. 263); second, even in the most neoliberal countries, the state has always mattered, particularly when it comes to securing the functioning of markets, maintaining the cohesion of social organizations, and resolving crises arising from neoliberalism (Harvey, 2005; Jessop, 2013). Especially in non-market areas such as environmental governance and climate control, state action is significant in creating and bolstering organizational structures.

Using a neo-Gramscian perspective, this article investigates the dynamic hegemony building processes in organizing the environmental governance of China's rare-earth industry over the past 30 years. Rare-earth elements 'are a group of 
metals with unique properties that make them indispensable in many high-tech products, in the clean technology sector and in various defense applications' (Hayes-Labruto et al., 2013, p. 55). Paradoxically, although rare-earths are indispensable to a myriad of intermediate and end users in 'clean' technology, the processes of mining, smelting and separating rare-earth ores can be heavily polluting. As the world's largest rare-earth producer, China has reaped considerable economic profits from the industry, but this has come at the expense of the natural environment (Wübbeke, 2013). In recent years, with ever more stringent environmental requirements from the central state on the rare-earth industry, environmental pollution in the upstream supply chain of many 'clean energy' industries has become a complex problem in China's environmental governance (ibid.).

Like other key industries, including extractive industries which are either directly or indirectly controlled and monitored by the state, China's rare-earth industry has always been regarded as an important national strategic asset (Moran, 2010). The extractive industries may represent 'an extreme case' of business-community conflicts and dynamics among the state, market and civil society (Banerjee, 2017, p. 5). This article - benefiting from rare access to the country's biggest rare-earth mining and mineral processing company - analyzes how the environmental impacts of this highly polluting industry have been governed in China, showing the changing relations of hegemony in what we identify as three environmental governance eras.

We problematize, in particular, the re-configuration of state power in reorganizing environmental contestations in China. We make use of Gramsci's (2007, p. 252) concept of 'passive revolution', which, for him, is a process controlled by dominant actors - in our case the state - that to some extent give in to popular demands in order to prevent a real revolution from taking place. 'Passive revolution' is hence a form of what Gramsci calls 'progressive restoration' (ibid.). In this context we also recognize the unique discourse of the 'dual role of civil society', envisaged by Gramsci as both a key ally in cementing hegemony, but also engendering power to disrupt hegemony (Levy and Newell, 2005). We problematize this 'dual role' by analyzing how Chinese NGOs and civil society have supported and challenged the state's governance of the rare-earth industry.

Thus, we particularly interrogate the following research questions: How have business-government-civil society relations, in the context of China's rare-earth industry, changed over the past 30 years? How have the severe environmental challenges, faced by this industry, been addressed? In what way has the central Chinese state retained power and control in the face of manifold top-down challenges and bottom-up pressures? How have the local corporatist ties been reinforced and re-organized? In what ways have civil society actors challenged or supported government actors in this re-organization process?

The article now unfolds as follows: We begin by discussing the neo-Gramscian governance literature in OS and related fields. We then introduce the case study of the rare-earth industry in China, and the methods used. This is 
followed by a detailed empirical discussion of the changing dynamics of China's rare-earth industry over the past three decades, outlining three environmental governance eras. We then discuss the processes of challenges and accommodation in the light of the neo-Gramscian literature with a focus on the disruption of hegemony in China's passive revolution. We conclude by discussing the key contributions and providing perspectives for future research.

\section{The neo-Gramscian approach in and beyond OS}

\section{The organization of hegemony in times of governance}

Drawing on Gramsci's (1971) concept of hegemony, the struggle over organizational fields has been understood as an important ongoing process in modern political bargaining and negotiation. In OS, 'hegemony' has been mainly applied to an understanding of the changing power relations between corporations and civil society in times of a move from government to governance (Girei, 2016; Spicer \& Böhm, 2007; Van Bommel \& Spicer, 2011). The term 'governance' has been regarded as 'a process of governing; or a changed condition of ordered rule; or the new method by which society is governed' (Rhodes, 2007, p. 1244), which includes political, social and economic dimensions (Crouch, 2006; Levy \& Spicer, 2013; Rhodes, 2007). Laclau and Mouffe (2001) re-conceptualize Gramsci's 'hegemony' as a broader form of social relation. Drawing on their ideas, several scholars highlight the hegemonic discourse of international businesses and organizations in global governance (see e.g. Böhm et al., 2008; Levy, 2008; Spicer \& Böhm, 2007; Wittneben et al., 2012). This so-called neo-Gramscian approach to conceptualizing hegemony has been applied to a bottom-up understanding of the assemblage of political, economic and discursive struggles in governance (Levy \& Newell, 2005), illustrating 'the processes of coalition building, conflict, and accommodation that drive social change' (Levy \& Egan, 2003, p. 803), while mostly focusing on the role of private actors such as NGOs and corporations.

Since at least the 1980s, the recognition of global environmental problems has been a new threat to hegemony and the sustainable organization of political economies and societies (Böhm et al., 2012; Levy \& Newell, 2005). Following the rapid growth of public concern about corporate environmental responsibility, Dawkins and Lewis (2003) use stakeholder theory to interrogate the implication of stakeholders for corporate social responsibility (CSR). Viveros (2004) and others particularly examines the trade-off between companies and multiple stakeholders in mining industries and discusses multi-stakeholder governance processes. More recently, the normative concept of political CSR has been developed to call for a new political role of companies to lead processes of addressing environmental and social challenges (e.g. Scherer \& Palazzo, 2011). While these contributions highlight the political nature of businessgovernment-civil society relations within the context of environmental governance, they rarely provide detailed insights into the multiple contestations and collaborations between these actors (Banerjee, 2012, 2017; Reinecke et al., 2012). 
Compared to stakeholder theory and political CSR, the neo-Gramscian approach shows how state agencies, corporations and NGOs are engaged in multiple and changing power struggles, forming alliances and frontiers of contestation. That is, they engage in "contests over the structures and processes that constrain and order industrial activities giving rise to environmental impacts' (Levy \& Newell, 2005, pp. 48-49). The neo-Gramscian perspective, thus, provides a theoretically coherent, dynamic and multi-dimensional way to integrate non-state actors - particularly NGOs and corporations - into the process of political contestation in environmental governance as corporations reorient themselves organizationally and strategically in the face of environmental challenges (Levy \& Spicer, 2013; Nyberg et al., 2013; Rothenberg \& Levy, 2012).

Previous studies in OS have specifically examined environmental governance issues from a neo-Gramscian perspective (see e.g. Levy \& Spicer, 2013; McGuirk et al., 2014; Nyberg et al., 2013; Pearse, 2010; Rothenberg \& Levy, 2012), sometimes emphasizing how environmental issues are pushed onto agendas by grassroots social movements and NGOs (MacKay \& Munro, 2012). However, these empirical organizational studies of neo-Gramscian governance have been set mostly within the context of Western, Anglo-Saxon 'liberal market economies' (Hall \& Soskice, 2001), often ignoring state actors. The OS field lacks somewhat behind other social science fields where there are a number of empirical studies that discuss the role of the state in relation to the political-economic formations of non-Western contexts. For example, Arnold and Hess (2017) governmentalize Gramsci in Cambodia's garment industry to discuss the interaction between labour struggles and state responses; Abrahamsen (1997) provides a holistic analysis of democratization in Africa; and Morton (2010) situates passive revolutions in diverse varieties of non-western contexts, covering Latin American, East Europe, and East Asia. There is hence a need in OS to go beyond Westerncentric, neo-Gramscian environmental governance research to include non-Western contexts, specifically understanding better the organization of hegemonic systems dominated by the state.

\section{Role of the state}

The main focus of neo-Gramscian studies in OS is usually placed on a pluralistic interpretation of Gramsci in contemporary alliance building. These studies have discussed, for example, the counter-hegemonic power of NGOs in transformative practice (Girei, 2016); collective agency in organizing counter-hegemonic challenges (Levy \& Scully, 2007); the corporate political strategies of European and US companies as well as the political struggles within civil society (Levy and Egan, 2003); corporate political engagement with climate change in Australia (Nyberg et al., 2013); the increasing influence of non-nation-state actors in global climate governance (Okereke et al., 2009); the information tactics employed by ExxonMobil and Greenpeace to win the battle over climate change (MacKay and Munro, 2012); 
the struggle over different climate imaginaries (Levy and Spicer, 2013); and the diverse political work in Australia's emergent landscape of urban carbon governance (McGuirk et al., 2014).

However, these studies pay little attention to the state and its role in contemporary hegemonic coalition making. Jessop (2002) blames this on a one-sided accentuation of neoliberalism and post-nationalism. Yet, the state still plays a pivotal role in 'securing the key conditions for the valorization of capital and the reproduction of labour-power as a fictitious commodity', having overall political responsibility for 'maintaining social cohesion in a socially divided, pluralist society' (Jessop, 2013, p. 8). Even in the most neoliberal Western countries, the state has always been important in creating and preserving the institutional framework for the neoliberal market (Harvey, 2005; Djelic \& Etchanchu, 2017).

Nevertheless, corporations often do maintain large power bases. With significant technological and financial resources, multinational companies in particular are key players in constructing the political economy of international environmental regimes (Levy \& Spicer, 2013; Rothenberg \& Levy, 2012). While corporations are often challenged and resisted by NGOs and social movements (Böhm et al., 2008), implementation of CSR and sustainability practices have repositioned some NGOs as partners of corporations (Levy et al., 2016). This has arguably widened the hegemonic coalition between corporate and civil society actors (Levy, 2008), leading political CSR scholars - such as Scherer \& Palazzo (2011) - to argue for a new political perspective of the corporation. While we acknowledge the rise of corporate power and private regulation forms (De Bakker et al., 2013), there has been too little analysis of the roles of governments and other state actors in the way hegemonic relations are organized in non-Western settings in OS field (see also Schrempf-Stirling, 2016).

In Gramsci, hegemony can be understood as a consensual order so that 'dominance by a powerful state may be a necessary but not a sufficient condition of hegemony' (Cox, 1981, p. 139). Although the necessity of state power is often overlooked by neo-Gramscian writers in OS, here we should be clear that Gramsci's idea of the state involves 'not only the apparatus of government, but also the private apparatus of hegemony or civil society ... the fact is that hegemony over its historical development belongs to private forces, to civil society - which is state too, indeed is the state itself' (Gramsci, 1971, p. 261). Yet this larger construction of the state is characterized by continuous struggle. As Levy and Newell (2005) remind us, Gramsci describes the dual role of civil society as both supporting and challenging state power. Hence it is important to refrain from seeing 'the state as a given or pre-constituted institutional category'; instead consideration must be given 'to the historical construction of various forms of state and the social context of political struggle' (Bieler \& Morton, 2004, p. 90). This means that the state - within a Gramscian perspective - should be understood as a socially contested process that produces different forms of state. 'In short, by considering different 
forms of state it becomes possible to analyze the social basis of the state or to conceive of the historical "content" of different states' (ibid., p. 91).

\section{Passive revolution}

Recently, the historical trajectory of the end of the 'cold war' and the increasing incorporation of formerly Communist or State Socialist countries into the fold of global capitalism has been analyzed as 'passive revolution', a key concept in Gramsci's (1971) Prison Notebooks. For him, a 'passive revolution' takes place when dominant elites are willing to implement, or even push for, changes "while retaining the essential existing features of organization and mode of functioning. Seen from this perspective, it can be argued that the Chinese party-state has also been in an uninterrupted process of "passive revolution" (Xing \& Shaw, 2013, p. 93). The word 'passive' means that the relatively weak hegemonic groups are relatively passively involved with a transformation process that is instigated from above (Levy \& Egan, 2003). Passive revolution 'typically occurs when challengers lack sufficient power to radically transform a regime' (Levy et al., 2016, p. 370). The molecular process of changes 'progressively modify the pre-existing composition of forces, and hence become the matrix of new changes' (Gramsci, 1971, p. 109).

The Gramscian passive revolution, as 'a strategy for managing change', emphasizes the progressive aspects of change in hegemonic building (Sassoon, 2001, p. 8). This allows us to understand contemporary Chinese hegemony as a top-down process of change that is embedded in a particular nexus of social, political and economic relations (Hui, 2017; Li and Christensen, 2012). China's recent transformation into a state capitalist system has hence been an elitedriven process which has allowed the country to enter the global marketplace, introducing competition at all levels while keeping relative social peace through a set of ideologies and hegemonic cultures of consent (Li and Christensen, 2012). This transformation can be seen as a 'passive' process of change because it has largely been lacking a nationalpopular base (Morton, 2010, p. 317). To better understand China's recent politico-economic and social transformation process through the lens of Gramscian conceptions of hegemony building and passive revolution, we turn to an empirical analysis of the environmental governance of the country's rare-earth industry over the past three decades.

\section{Methodology}

\section{Research context}

Environmental governance signifies 'the broad range of political, economic, and social structures and processes that shape and constrain actor's behavior towards the environment' (Levy \& Newell, 2005, p. 2). In line with an inductive focus this article employs a qualitative case study approach to discuss the changing roles of the five main actors - the 
central state, local government, the largest state-owned rare-earth company as well as local NGOs and residents - as well as their dynamic hegemony building processes in organizing the environmental governance of China's rare-earth industry over the past 30 years.

The mother lode of global rare-earth oxides resides in northern China. With scant environmental concern shown by the central state before the 2000s, the industry has generated significant amounts of toxic waste, blighting the local environment. According to an NGO director we interviewed, in the late 1990s, more than one hundred rare-earth tailings dams, which are used to store mining byproducts, emerged around the major mining sites. They are saturated with all sorts of toxic chemicals and radioactive elements. The biggest tailings dam, covering over 10 square kilometers, looks like a big lake from the air. On the ground, however, the lake becomes a murky expanse of toxic water with no biological survival, heavily poisoning the local environment.

Our case study focuses on a typical local state-owned enterprise (SOE), as SOEs in China include not only corporations invested in and owned by the central state but also those invested in and owned by local governments. The local SOE was established in 1961 with the mission to explore the world's largest rare-earth treasure in China, and its development and integration represent the entirety of the Chinese rare-earth industry. Thus the case study remembering that the extractive industries are national strategic assets in China - provides a paradigmatic example of the characteristics of the environmental governance regime with a particular focus on the changes of China's top-down 'passive revolution' over the past 30 years.

\section{Data collection}

To carry out the case study, enriching the neo-Gramscian approach (Eisenhardt, 1989), data was mainly collected from interviews, triangulated with a wide range of documentary data. One of the authors grew up in the local area in China, providing rich experience of and access to the world's largest rare-earth supplier, local government agencies as well as local green NGOs and residents. The semi-structured interviews - with three local government officers, five corporate senior managers, eight NGO directors, and twenty residents - were conducted face-to-face in person in China between April 2013 and August 2013 and between July 2015 and August 2015, representing rare access granted to this strategically important Chinese industry. The three local government officers are separately responsible for local economic and business development; local environmental governance; and local development strategies. The five corporate managers are separately responsible for procurement and marketing; production and technology innovation; corporate social responsibility; production security, media reception and public relations; and overall corporate strategies. The eight directors are from four local green NGOs and four leading grassroots environmental NGOs in 
China. All have been working at their respective positions for over five years, providing deep and unique insight into the environmental governance of China's rare-earth industry based on their rich work experience.

The interviews usually lasted one hour, starting with a series of fixed questions about interviewees' options on the changing roles of the state, business and civil society in the development of environmental governance of China's rareearth industry. Then the interviewees were asked about their environmental contestations in coordinating sustainable development and profit maximization. According to interviewees' positions and responses, the fixed questions were followed by a range of open questions about their understanding of the processes of challenges and accommodation in approaching green growth. All interviews were conducted in Chinese and recorded through intensive note-taking. The author from China then translated all transcripts from Chinese to English. In order to confirm that there was no discrepancy or ambiguity between what the author translated and what the interviewees presented, the translated transcripts were emailed respectively to the interviewees for confirmation.

To support our interview data, we collected a wide range of relevant documentary material with focuses on organizing China's rare-earth industry, amounting to over 300 publicly available documents. The actual data gathering started in 2012 and finished in 2017. We selected over 70 closely-related documents among this data for summarizing, categorizing and coding. The documentary data we finally gathered have close links to the development of the environmental governance of the rare-earth industry over the past 30 years, including: first, government documents released by the central state and the different levels of local governments such as 'Opinions', 'Suggestions', 'Regulations', 'Announcements', 'Guides', 'Consults', 'Plans' and 'Industrial White Books' since the 1980s; second, corporate documents such as annual social responsibility reports from 2009 to 2016, annual reports from 2011 to 2016 and annual self-monitoring reports from 2013 to 2016; third, NGOs' environmental monitoring reports and relevant environmental information disclosure posted on their websites since the 2000s; and, fourth, relevant media articles published by three major Chinese business media portals (National Business Daily, Xinhua News and Money 163) and internationally renowned news providers (including Reuters, Guardian, Daily Mail, New York Times) over the past 20 years. Table 1 provides an overview of our main data sources.

Table 1. Overview of data sources.

\begin{tabular}{llll}
\hline Category & Data Source & Code & Number \\
\hline Interview & Local governmental officer & LGOV & 3 \\
& Corporate manager & COM & 5 \\
& NGO director & NGO & 8 \\
& Local resident & RES & 20 \\
\hline Document & Central state document & G-DOC & 14 \\
& Local government document & LG-DOC & 7 \\
& Corporate document & C-DOC & 17 \\
& NGO document & N-DOC & 12 \\
& Media document & M-DOC & 22 \\
\hline
\end{tabular}




\section{Data analysis}

With the confirmation of interview contents from all the interviewees, we started to code the contents of interview transcripts for qualitative analysis triangulated with a comprehensive collection of documentary data. First, all primary and secondary data were summarized, categorized and coded to delineate the different organizational processes of the five main actors in the neo-Gramscian governance framework. We identified 26 first-order codes based on their different interests and activities in organizing the rare-earth industry, shown as the 'Sample data extracts' in Table 2. In order to fully comprehend the changing story over the past 30 years, we then organized the first-order codes and their respective extracts in chronological order, accounting for the changes of the five major actors' involvement in building and contesting the hegemony of China's environmental governance.

During the process of creating the chronological map, we realized that the whole hegemony building process of organizing the environmental governance of China's rare-earth industry was characterized by two main turning points. First, at the beginning of the 2000s, a series of significant events took place, such as China's accession to the World Trade Organization (WTO), and the convening of the Third Plenary Session of the 16th Central Committee of the Communist Party of China (CPC), which proposed 'Scientific Outlook on Development' to reappraise China's development guidelines. Nearly all our interviewees from government, business and NGOs mentioned the significant change of organizing China's rare-earth industry before and after the beginning of 2000s. Another key turning point was recognized in the recent development of China's rare-earth industry; namely the 2012 environmental assessment. Most of the main codes extracted from the interview transcripts to explain the recent organizational processes have certain links with this contested event and all five actors were involved in. Therefore, we organized all the first-order codes into three eras - we named them as 'mass production era - 1990s', 'transition era - 2000s-2012', and 'nascent sustainable development era - 2012-to date' (see Table 2).

With an in-depth analysis of the changing organizational processes of five actors as well as their dynamic environmental contestations in the three eras, we abstracted 9 second-order themes as the main hegemony building processes that describe the changing environmental governance regime in China, and also grouped them in three eras (see Figure 1).

At the end of the data analysis, based on the 9 second-order themes, we identified three aggregated dimensions 'top-down growth hegemony' to 'reorganizing hegemony' and then to 'green growth hegemony' - for three eras of hegemonic changes in organizing China's rare-earth industry. Based on the analytical coding process shown in Figure 1, we now discuss the re-configuration of state power and the changing hegemonic positions of non-state actors before and after the two turning points in the evolving hegemony building processes of organizing the environmental governance of China's rare-earth industry during the past 30 years. 
Table 2. Sample data extracts of the first-order codes.

\begin{tabular}{|c|c|c|}
\hline Era & First-order concept & Sample data extracts \\
\hline \multirow{9}{*}{ 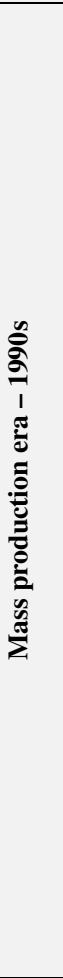 } & Central planning & $\begin{array}{l}\text { In the past the state implemented extremely tight ideological and social control in the form of 'command'. (LGOV1) } \\
\text { The 'highly prescriptive plans' determined everything in China. (COM1) } \\
\text { We [the local SOE] operated more like a 'processing plant' without any autonomy. (COM3) }\end{array}$ \\
\hline & $\begin{array}{l}\text { Rapid } \\
\text { industrialization }\end{array}$ & $\begin{array}{l}\text { In order to satisfy the massive population's basic needs in a relatively short period, the central planning focused mainly on } \\
\text { rapid industrialization and economic growth. (LGOV3) } \\
\text { China focused on the expansion of SOEs' production capability, especially for heavy industries. (COM5) }\end{array}$ \\
\hline & $\begin{array}{l}\text { Inefficient } \\
\text { administration }\end{array}$ & $\begin{array}{l}\text { The local government's inefficient regulation and control on this traditionally protected but newly opened sector as well as } \\
\text { the information distortion between the central state and the local SOE might be the main reason for the mining chaos in the } \\
\text { 1990s. (COM3) } \\
\text { The 1990s economic system not only lacked incentive systems and performance measures, but also lacked concern regarding } \\
\text { environmental performance. (NGO2) }\end{array}$ \\
\hline & $\begin{array}{l}\text { Ignoring of } \\
\text { environmental } \\
\text { awareness }\end{array}$ & $\begin{array}{l}\text { There was no environmental pressure on the local SOE ... as there was not enough environmental awareness of the rare-earth } \\
\text { industry in the central state. (NGO7) } \\
\text { As a result, environment became the biggest 'victim' of the rapid economic growth. (NGO3) }\end{array}$ \\
\hline & Traditional ties & $\begin{array}{l}\text { We [the local government], in terms of the central instructions, were fully responsible for everything of the local SOE and } \\
\text { retained all profits and bore any loss. (LGOV1) } \\
\text { We [the local SOE] are a fully local state-owned enterprise. (COM4) }\end{array}$ \\
\hline & Mass production & $\begin{array}{l}\text { We were forced to maximize outputs, no matter the environmental costs. (COM5) } \\
\text { The temptation to higher profit and the lower entry barriers of the local rare-earth industry attracted } 150 \text { private firms, many } \\
\text { of which operated illegally, chasing profits through immoderate mining and processing. (N-DOC1) }\end{array}$ \\
\hline & $\begin{array}{l}\text { Environmental } \\
\text { pollution }\end{array}$ & $\begin{array}{l}\text { Under the central guideline of maximizing outputs at any cost, SOEs had neither extra energy nor extra money to engage in } \\
\text { environmental governance. (NGO1) } \\
\text { The most serious problem caused by mass production was environmental pollution. (RES1) } \\
\text { The rare-earth mining chaos depleted most of the original mine resources in China. (G-DOC1) }\end{array}$ \\
\hline & $\begin{array}{l}\text { Public } \\
\text { acquiescence }\end{array}$ & $\begin{array}{l}\text { Today's politics still retain the 'big-government' overtone of over 5,000 years of autocratic ruling history of one-party } \\
\text { dominance in China. (LGOV3) } \\
\text { The central state was fully committed to boosting industrial outputs to guarantee people a basic standard of living, in return } \\
\text { for their voluntary acceptance of central planning. (NGO8) }\end{array}$ \\
\hline & Restricting NGOs & $\begin{array}{l}\text { Before the 1990s, NGOs were strictly forbidden to exist. (NGO7) } \\
\text { Friends of Nature, as the first grassroots environmental NGO in China, was established in 1993. (NGO8) }\end{array}$ \\
\hline \multirow{10}{*}{ 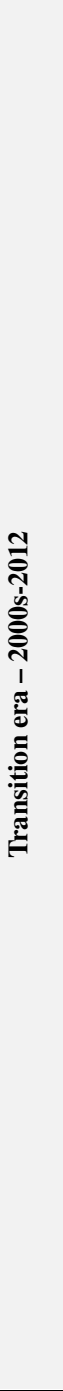 } & $\begin{array}{l}\text { Accession to the } \\
\text { WTO }\end{array}$ & $\begin{array}{l}\text { Especially after accession into the WTO in 2001, China has been widely criticized as one of the largest greenhouse gas } \\
\text { emitters in the world. (LGOV2) } \\
\text { Facing strict international standards and heightened international pressure on green competitiveness, China has begun to } \\
\text { elevate the importance of environment protection so as to mitigate criticism at home and abroad. (NGO5) }\end{array}$ \\
\hline & $\begin{array}{l}\text { Building } \\
\text { harmonious society }\end{array}$ & $\begin{array}{l}\text { Building a 'harmonious society' is China's vision as the ultimate goal of 'Scientific Outlook on Development'. (G-DOC7) } \\
\text { China's economic success enabled our state to be more engaged in solving costly environmental issues. (LGOV3) } \\
\text { 'Scientific Outlook on Development' sets environmental protection as a factor critical to socio-economic development and as } \\
\text { a test of how well the state can serve the people and build its capabilities. (COM1) }\end{array}$ \\
\hline & $\begin{array}{l}\text { Government } \\
\text { regulation }\end{array}$ & $\begin{array}{l}\text { Reacting to the increasing international pressures and domestic contestations, the 'Cleaner Production Promotion Law' was } \\
\text { issued in 2003, encouraging public participation in environmental monitoring, requiring relevant institutions to disclose local } \\
\text { environmental information, securing for the public the right to know. (NGO6) } \\
\text { The } 2008 \text { National Mineral Resource Plan put the rare-earth industry strictly under government control. (COM4) }\end{array}$ \\
\hline & $\begin{array}{l}\text { Industrial } \\
\text { Consolidation }\end{array}$ & $\begin{array}{l}\text { The '2009-2015 Rare-Earth Industry Development Plan' decided to consolidate the rare-earth industry into the three large } \\
\text { SOEs, in order to establish strong systems of pricing, marketing and environmental governance. (G-DOC10) } \\
\text { All kinds of rare-earth resources and raw materials products are franchised by [the local SOE]. (LG-DOC4) } \\
\text { The direct reason for private firms joining us was the lack of rare-earth supply... as we rely on the local government for } \\
\text { legitimacy and resource, and the local government also relies on us to achieve economic goals. (COM2) }\end{array}$ \\
\hline & $\begin{array}{l}\text { Local achievement } \\
\text { assessment }\end{array}$ & $\begin{array}{l}\text { Since 2003, assessment of local government achievements has no longer been restricted to economic growth, but also related } \\
\text { to environmental performance. (LGOV3) } \\
\text { Any local discontent and demonstrations will directly influence the local government performance in achievement evaluation } \\
\text { in the aspect of social stability and environmental governance. (NGO2) }\end{array}$ \\
\hline & $\begin{array}{l}\text { Local policy } \\
\text { implementation }\end{array}$ & $\begin{array}{l}\text { With increasing emphasis on environmental performance, local government has to follow new central development } \\
\text { principles, but sometimes implements them with a degree of adjustment to promote local economic growth. (NGO7) } \\
\text { We think the central state environmental policies are developed at a macro-level, not 'tailored' to local governance situations } \\
\text { and industrial relations... [However], we are not the shelter of the local SOE any longer in environmental governance, only } \\
\text { providing necessary support and supervising its green performance. (LGOV3) }\end{array}$ \\
\hline & $\begin{array}{l}\text { Dual } \\
\text { administration }\end{array}$ & $\begin{array}{l}\text { Civic NGOs have been developing significantly in terms of number, scope, capacity and impacts since 2000s, and shaping } \\
\text { the trajectory of civil society development in China. (N-DOC8) } \\
\text { To register as a formal NGO, one must obtain sponsorship from a local government institution. (G-DOC8) } \\
\text { The state and NGOs are maintaining a love-hate relationship. (NGO7) } \\
\text { Dual administration system is the biggest legal barrier for the vibrant civil society to consolidate. (NGO5) }\end{array}$ \\
\hline & $\begin{array}{l}\text { Environmental } \\
\text { monitoring }\end{array}$ & $\begin{array}{l}\text { With increasing emphasis on sustainable development and environmental governance, the state has been increasingly tolerant } \\
\text { of civil society's participation in environmental monitoring. (LGOV2) } \\
\text { We are exercising weekly environmental monitoring in a local rare-earth mining area. (NGO3) }\end{array}$ \\
\hline & Publicizing & $\begin{array}{l}\text { Although the media is not strictly regarded as a part of governance, it has been the most important means for us to disclose } \\
\text { environmental monitoring information and express green appeal. (NGO5) } \\
\text { We are committing to reporting environmental damage in a timely manner to local governments before irreversible } \\
\text { environmental consequences emerge. (NGO3) }\end{array}$ \\
\hline & Local resisting & $\begin{array}{l}\text { With the increasing concern from the central state, we finally 'see hope' of the payoffs and had embarked on a long road } \\
\text { bargaining with the local SOE. (RES5) } \\
\text { The SOE claimed that it should not be responsible for the losses caused by the mining chaos in the 1990s. (NGO3) } \\
\text { Our losses, including crop loss, livestock deaths and treatment of diseases, need to be compensated. (RES3) } \\
\text { Without satisfactory payoffs, a lot of demonstrations were organized. (NGO1) }\end{array}$ \\
\hline
\end{tabular}




\begin{tabular}{|c|c|c|}
\hline \multirow{7}{*}{ 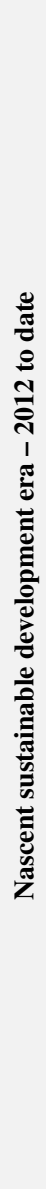 } & $\begin{array}{l}\text { Environmental } \\
\text { performance } \\
\text { assessment }\end{array}$ & $\begin{array}{l}\text { In May } 2011 \text { the State Council issued ['Guidelines'], putting resource protection and environmental sustainability in first } \\
\text { place in further sustainable development (G-DOC3). } \\
\text { In April 2012, the State Council approved the establishment of the Association of China Rare Earth Industry, with the aims of } \\
\text { assisting government to develop environmental policies and call for self-discipline from the industry (G-DOC9). } \\
\text { The } 2012 \text { environmental assessment is an important 'turning point'. (NGO6) } \\
\text { The [local SOE's] name eventually appeared on the third list of environmental assessment but followed by a bracketed label } \\
\text { 'smelting separating section'. (M-DOC1) }\end{array}$ \\
\hline & $\begin{array}{l}\text { Government } \\
\text { support }\end{array}$ & $\begin{array}{l}\text { The central state issued clear instructions to [the local SOE] and required us to provide all-round support... we made it a } \\
\text { priority to assist it in carrying out practical plans, allocating the funds and implementing practices effectively. (LGOV3) } \\
\text { The local government invested } 6 \text { billion RMB Yuan to help govern tailings dams and expand sewage treatment ponds and } \\
\text { waste recycling pools. (M-DOC1) }\end{array}$ \\
\hline & Green upgrade & $\begin{array}{l}\text { We invested } 2.2 \text { billion RMB Yuan in upgrading production, emission and recycling facilities. (COM4) } \\
\text { In the four fiscal quarters of 2012, we generated } 4854.82 \text { tons of coal waste (general waste), which was acquired by [W] } \\
\text { Environmental Brick Factory; and generated } 4.1 \text { tons of waste mineral oil (hazardous waste), which was acquired by [H] } \\
\text { Renewable Resources Corporation. (C-DOC12) } \\
\text { From } 2011 \text { to 2012, over forty million RMB Yuan were invested in the environmental governance of China's rare-earth } \\
\text { industry, which significantly improved the green performance of the whole industry. (M-DOC2) }\end{array}$ \\
\hline & Mediating & $\begin{array}{l}\text { We can represent the residents to negotiate with the SOE and the government, avoiding direct confrontation between the two } \\
\text { sides. (NGO1) } \\
\text { Our mediation can be much more easily accepted by all parties, to avoid endless bargaining. (NGO3) } \\
\text { We trust NGOs as the third-party mediator. (RES11) }\end{array}$ \\
\hline & Compromising & $\begin{array}{l}\text { Under increasing pressure to secure sustainable development and social stability from the central state, the payoff dispute } \\
\text { needed to be resolved as soon as possible. (COM5) } \\
\text { The government and the SOE accepted liability to make payoffs. (NGO2) } \\
\text { We jointly funded } 500 \text { million [RMB] Yuan to implement the overall relocation of five nearby villages' farmers close to the } \\
\text { biggest tailings dam. (COM2) }\end{array}$ \\
\hline & $\begin{array}{l}\text { Establishing } \\
\text { Department Three }\end{array}$ & $\begin{array}{l}\text { We are established to coordinate the decision-making [of Department } 1 \text { and Department 2]. (LGOV3) } \\
\text { In 2012, all the other departments were coordinated by [Department Three] to provide full support for the local SOE's } \\
\text { environmental rectification plans. (NGO4) } \\
\text { Our supervision role continues to help the local government to rebalance economic growth and environmental protection. } \\
\text { (LGOV3) }\end{array}$ \\
\hline & $\begin{array}{l}\text { Increasing } \\
\text { commitment }\end{array}$ & $\begin{array}{l}\text { We earnestly fulfill the requirements of the '2015 New Environmental Protection Law', continue to achieve new } \\
\text { breakthroughs in clean production, pollution reduction and risk prevention. (C-DOC10) } \\
\text { The New Law added the accountability clause to regulate local government adjustments in the implementation of the central } \\
\text { environmental policies. (LGOV2). } \\
\text { Government authorities have tolerated most unregistered NGOs' existence, shifting focus from the 'legality of NGOs' to the } \\
\text { 'legality of their activities'. (NGO8) }\end{array}$ \\
\hline
\end{tabular}

Figure 1. Analytical coding process.

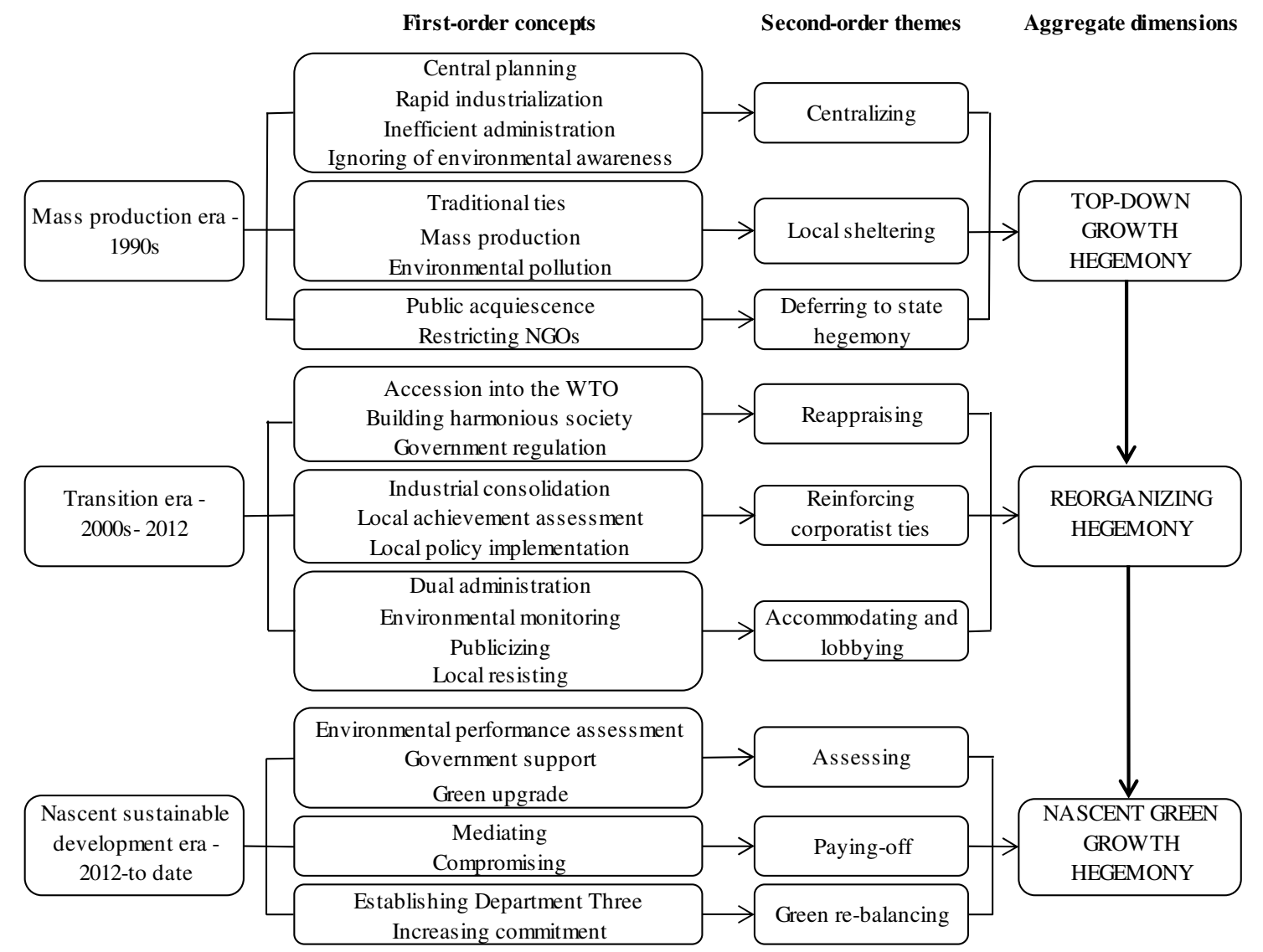




\section{Building and contesting hegemony in organizing China's rare-earth industry}

Our data analysis maps out three eras for the changes of hegemony over the past 30 years: mass production era, transition era, and nascent sustainable development era. To apply the neo-Gramscian approach, we identify five major actors - the central state, local government, local SOE, local NGOs, and local residents - involved in dynamic environmental contestations, recognizing the changing themes of hegemony building processes among the different actors.

Figure 2 visualizes the dynamics among five actors, representing the changing organizational processes in hegemony building of the three eras. Based on the second-order themes of hegemony building processes, shown as Bold arrows in Figure 2, we now discuss the re-regulation and re-configuration of state power in constructing China's contemporary environmental governance regime and interrogate the different hegemonic positions of non-state actors and their dynamic interactions with government agencies.

\section{Mass production era}

From the foundation of 'New China' in 1949 to the 1990s, China had experienced a long period of planned economy to promote the progress of industrialization. The central state conceptualized its hegemony in terms of leading a series of successes in World War II and national independence. To initiate rapid recovery of the national post-war economy, the state nationalized all means of production and set up a planned economy based on control of SOEs.

Our case study SOE was founded by local government in 1961 and heralded the start of the rare-earth industry in the post-war 'New China'. Within the first era of central planning and mass production, as shown in Figure 2, we now interpret the three hegemony building processes - centralizing, local sheltering, and deferring to state hegemony - in organizing China's rare-earth industry during the 1990s.

Centralizing. After the foundation of 'New China', with a very low level of industrial development and massive population growth, the central government faced serious market failure with scant agricultural surplus and tight supply and demand. To improve living standards in return for public acquiescence to central planning, rapid industrialization had been set as the only target for the central state, local governments and the whole business sector. The central state developed prescriptive plans for mining, producing and distributing, and required the local government to implement these at the corporate level and guarantee SOEs' annual production quotas. As a government officer further explained: 


\section{Mass production era - 1990s}

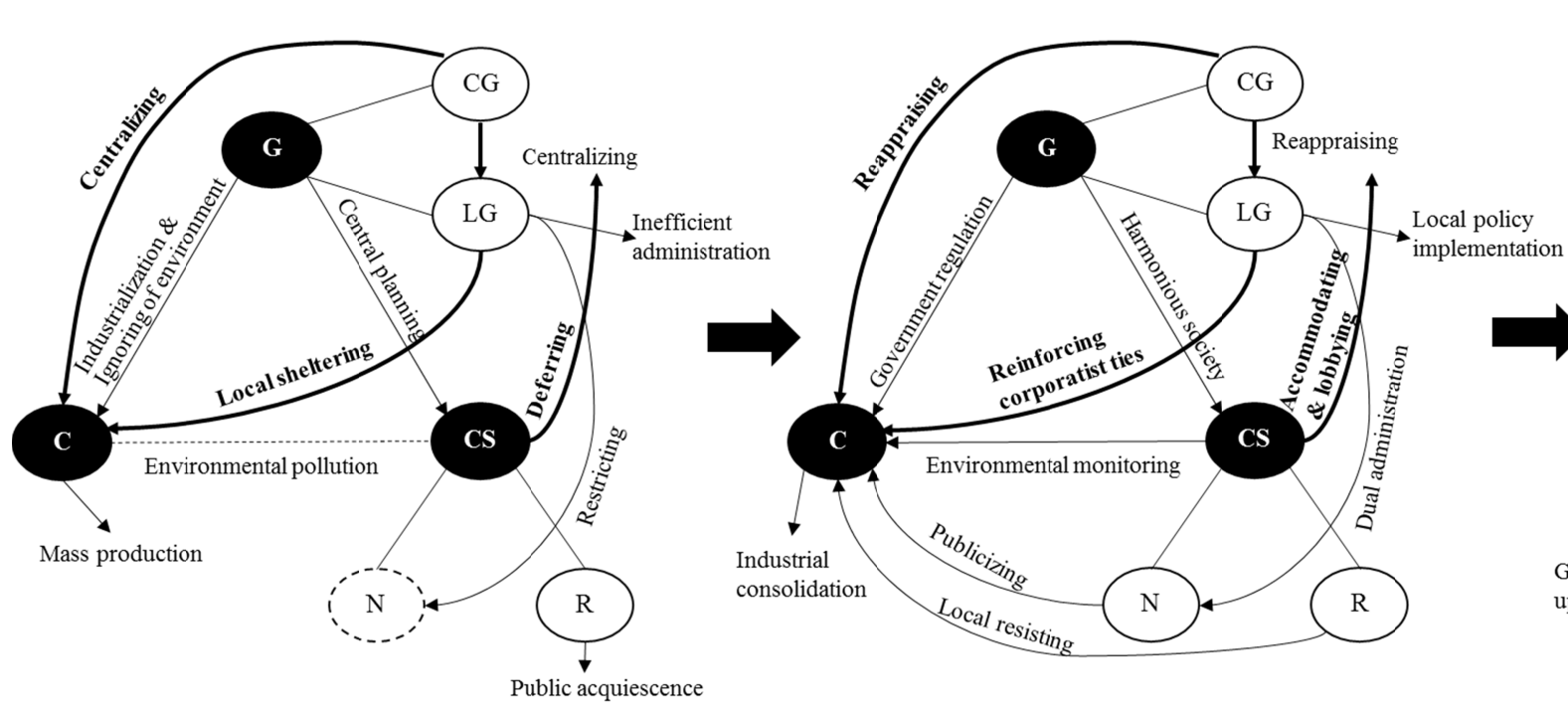

Nascent sustainable development era -2012 to date

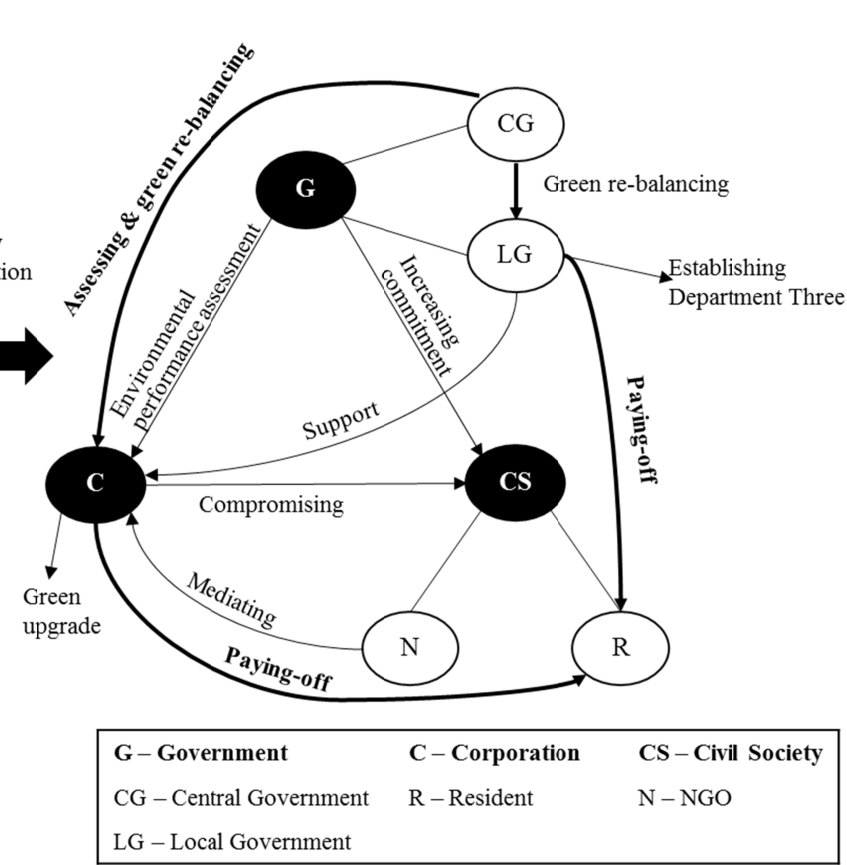


The main function of central planning was to do with the aim of realizing rapid industrialization ... the central planning prioritized the development of heavy industries at any cost, in order to rapidly transform China from an agrarian country to an industrialized country. (LGOV3)

As a result, the high-speed development of China's rare-earth industry generated a huge amount of waste water, gas and residue and seriously polluted the local ecological environment. Focusing on output maximization and economic growth, neither local government nor SOE were involved in environmental governing activities.

At the same time, with deepening opening-up and reform, the traditionally protected rare-earth industry has been gradually opening to domestic private enterprises since the early 1990s. However, with inefficient administration and government control at the initial stage of market-oriented reform, serious mining chaos emerged in the local area. Over 100 private firms with low-level techniques and very rudimentary equipment flocked to the rare-earth industry and caused huge resource waste and serious environmental pollution.

Local sheltering. Under the centralized economy in the 1990s, local government was fully responsible for the SOE's daily operations. Traditionally many key industries including extractive industries were either directly or indirectly tied to or controlled by the state. The local SOE was always protected by the local government in the 1990s, while fully engaging in mass production and achieve specified output requirements set by the central state, without any consideration of environmental pollution in the process of mining, smelting and separating rare-earths. A corporate manager explained why there was no environmental burden on the corporate level:

Local government was responsible for cleaning up all 'messes' [of us] and we were required to maximize production capability and achieve the central state's output requirements at any costs. (COM1)

At the beginning of China's modern industrialization in the 1990s, advanced technologies and facilities, outstanding research and development teams, and strong government supports necessary for improving environmental performance would be difficult to coordinate. As a result, without central planning on sustainable development, green awareness was foreign to the business sector and the public, and environmental governance gave way to output maximization and economic growth under the mass production model.

Deferring to state hegemony. As a single-party regime - 'a rule of persons' tradition more specifically - the historical trajectory of one-party dominance over 5,000 years has heavily shaped the hegemony building in the 'New China'. After leading a series of successes in national security and rapid economic growth during China's planned economy, the 
CPC had established a broad, deep and reliable mass base to achieve public acquiescence during the 1990s. An NGO director confirmed:

With the singular faith of 'without the CPC there would be no New China', the civil society unconditionally followed the central planning. (NGO6)

Thus in the initial stage of China's industrialization during the 1990s, the state took strict controls over economic structure and ideological and social discourse. Although the top-down decision-making system has been widely criticized concerning the effectiveness of green growth planning and implementation, non-state actors were still subject to hegemony of the state, and NGOs which could have advocated for environmental concerns were severely restricted.

\section{Transition era}

Since the early 2000s, the established top-down growth hegemony in China has been seriously challenged by a range of supranational and internal factors. Western thought started to influence central decision-making and improve public environmental awareness. At the same time, social conflicts at the local level also intensified due to, often severe, local environmental degradation. In order to deal with this dual crisis, which challenged the state's hegemonic control, the central state proposed, in 2002, the 'harmonious society' programme, accommodating top-down and bottom-up pressures. Part of the overall logic of this programme was, faced by the world's highest economic growth and carbon emissions rates, the ecological modernization paradigm (Spaargaren \& Mol, 1992), which was seen as 'legitimate' to mitigate international and domestic criticisms.

Within the transition era, as shown in Figure 2, we now illustrate the three-evolving hegemony building processes during the 2000s - reappraising, reinforcing corporatist ties, and civil society accommodating and lobbying - in reorganizing China's rare-earth industry.

Reappraising. With the deepening of opening-up the central state started to reappraise the existing logics of economic growth, particularly for the development of traditionally polluting heavy industry. In the wake of China's accession into the WTO in 2001, dramatically increasing international standards and market demands, have brought about reappraisal of the environmental dimension of organizing China's rare-earth industry. As detailed by a government officer:

Western multinationals started to find the rare-earth material suppliers in China and brought with them environmental policies and technologies. The external pressure on the supply chain has been gradually internalized in China's suppliers... at the same time, 
the reduction of tariffs made our heavy industries more likely to import raw materials and ease the domestic environmental pressure. (LGOV2)

The traditional mass production model accompanied by low-quality labour, poor technical level, high energy and resource consumption, and extensive environmental degradation left productive forces lagging behind Western countries. At the same time, rising public green awareness and vibrant development of green NGOs also challenged the traditional development mode. To accommodate growing challenges at home and abroad, an NGO director recalled the central state proposed a new development principle for the construction of 'harmonious society':

Confronted with a sharp rise in environmental pollution and corresponding growing discontent of civil society and global criticisms, the central state proposed the 'Scientific Outlook on Development' to highlight the sustainability concept, improve the living environment and reassure the public, ultimately building a harmonious society. (NGO8)

Since then, sustainable development has been set as one of the most important ingredients in the assessment of economic and social development in China. With further engagement in globalization, reacting to the dramatic growth of global rare-earth demands and the continuous decline in export prices of China's rare-earth materials, the central state realized the importance of rare-earths as a strategic resource for China's economic development and environmental governance, and started to consolidate, reorganize and regulate the whole rare-earth industry.

Reinforcing corporatist ties. After a new 'Scientific Outlook on Development' was proposed, a series of governance and consolidation plans have been carried out to integrate China's rare-earth industry. These were intended to establish an integrated supply chain and an effective environmental governance system. In 2009, the final 'Plan' was issued, requiring the local SOE to integrate all rare-earth enterprises in northern China via different strategies of mergers and acquisitions. In fact, under ever-stricter mining control from the central state, the only way for private rare-earth firms to survive in northern China was to join the local SOE.

The consolidation process possessed strong overtones of 'big-government' in which local authorities, under prescriptive instructions, helped the local SOE to integrate the rare-earth industry in northern China via mandatory administrative measures. At the same time, new 'political ties' were built. The local SOE relies on local government for legitimacy and critical resources, while the local government is heavily dependent on the SOE to fulfil political and financial goals. As further explained by an NGO director: 
Such a kind of mutual economic dependence, 'corporatism', is particularly manifested in this strategic industry. The ingrained principle of maximizing profit is maintained to improve local government economic achievement, in return for obtaining access to the strategic resource and mining right from local government. (NGO1)

Thus, local administrations used to seek to make adjustments to central government environmental policies, which were however difficult to practically implement. With the deepening process of reappraising the development of China's rare-earth industry, local government achievement assessment has been no longer restricted to economic growth but also related to social stability and sustainable development. An NGO director explained why the new assessment scheme led to power struggles between regional and national governance:

The new [corporatist] ties led the local government to be both a 'referee' and a 'player' in environmental governance... if environmental policies are changed a lot, the central state will blame local government as a shelter for corporate polluting activities; however, if environmental policies are implemented strictly, the local economic output will be inevitably affected, which would also raise alarm bells in local achievement assessment. (NGO4)

With increasing media exposure of local pollution issues and growing payoff requests, the local government admitted the existence of tailings dam issues while attempting to conceal the seriousness of pollution. The environmental contestations culminated in the 2012 environmental assessment. Local government had to be seen to take responsibility for environmental remediation with the SOE, although it stated that it would no longer help the SOE to rectify the damage.

Accommodating and lobbying. The 1990s' market-oriented reform has led to a gradual relaxation of Party control over public discourse, which provided opportunities for environmental NGOs' survival and development. NGOs have emerged since the 1990 s and gained footholds to shape the trajectory of civil society development, although always under government restrictions. The state maintains contradictory attitudes: On the one hand, the state allows NGOs to operate and provide certain social services that the government cannot deliver well; on the other hand, the fear and suspicion of NGO activism challenging authorities has resulted in strict government control - implementing a dual administration system - over NGO activism.

Since the mid-2000s, with a largely non-oppositional stance towards government and relying on the increasing influence of mass media, environmental NGOs made limited but inspiring progress in local environmental monitoring and information disclosure. In our case study: 
Several green NGOs held a press conference in 2006 to expose the serious environmental pollution of rare-earth tailings dams, which attracted extensive concern from local residents, government agencies, international NGOs and global media. (NGO3)

Their publicizing activism also attracted unprecedented attention from the central state. Reacting to pressures from both the international market and civil society, the central state started to reappraise the growth of local SOE. Also, after NGOs' publicizing of the issues, local resistance was triggered, as the locals accessed more data on the severe pollution caused by rare-earth mining and refining processes, for example, as noted by one resident:

The development of the rare-earth industry caused severe damage to our five surrounding villages and ruined over 3000 villagers' lives here. Most locals have fled during the past ten years. We suffered from different diseases like osteoporosis, diabetes and chest problems. (RES4)

As a result, in the whole process of industrial consolidation since 2009, when local residents heard that nearby rareearth corporations were acquired by the local SOE, which possessed sufficient economic strength, they gathered immediately to ask for payoffs. However, an agreement over the payoff amount between the local residents and SOE was always difficult to reach. The locals appealed for the payoff for losses for at least the past 20 years, but the local SOE claimed innocence for the 1990s' mining chaos, which is regarded as the root of the local environmental deterioration.

Thus, the payoff dispute between residents and the local SOE lasted over three years, and was intensified by the 2012 environmental assessment, which is regarded as a start of the nascent sustainable development era. In 2012, as local resistance influenced the appraisal of achievements of local government in constructing a 'harmonious society' and the environmental assessment of the local SOE, they had to seek the most efficient way to resolve the dispute. As a result, local NGOs started to play a dual role, representing grievances but also mediating local disputes and making recommendations for compensation.

\section{Nascent sustainable development era}

Over the past five years, with increasing commitment to achieving sustainable development, there has been a new hegemonic assemblage combining environmental governance and responsibility with economic growth. The 2011 State Council document, 'Guidelines on promoting the sustainable development of China's rare-earth industry', promoted the implementation of the 2012 environmental assessment, which was a key turning point and area of conflict in reorganizing China's rare-earth industry since the 2000s. 
Within the third era of nascent sustainable development, as shown in Figure 2, we now explain the recent three hegemony building processes - assessing, paying-off, and green re-balancing in approaching nascent green growth hegemony in China.

Assessing. Since 2011, in order to promote environment-friendly development of China's rare-earth industry, the MEP has begun to engage in stricter environmental monitoring and assessment measures, publishing a list of environmentally friendly enterprises annually. Without inclusion on this list, corporations face suspension of production and loss of export quotas allocated by the Ministry of Commerce (MC). As the world's largest rare-earth supplier, the local SOE has always been approved with the largest export quota. However, in 2012 its name did not appear on the first list of qualified export enterprises published by the MC since it failed to pass the first and second environmental verifications conducted by the MEP. A Chinese media portal reported the detail:

In July 2012, [the local SOE] was warned that a failure to gain inclusion on the third environmental verification list would mean immediate production suspension and loss of export quota for the following year. (M-DOC5).

Facing the final warning, the local government invested a huge amount of money to help the local SOE to realize a green upgrade in a short period of time. With huge financial and technical support from local government, the SOE was committed to improving green performance by upgrading production equipment and establishing emission and recycling facilities. Finally, it passed the 2012 environmental assessment by improving emission control in the process of rare-earth smelting and separating and shelving its mission of governing the tailings dams.

In the assessing process, the central state played a key role in pushing local government to collaborate with the SOE to improve environmental performance. The local SOE has been given more autonomy for environmental governance while local government has taken stricter measures to monitor and support the SOE's operations to abide by national environmental policies, in order to avoid penalties for environmental misconduct. The features of corporatism have been gradually shifting from mutual dependence for economic expansion to mutual support for green growth, as environmental performance has been one of the most significant standards for evaluating corporate market competitiveness and local government achievement in China.

Paying-off. With the central state's increasing environmental emphasis, local farmers and villagers had embarked on a bargaining process with local rare-earth industry, appealing for payoffs for their losses. The dispute not only influenced the normal operations of the local SOE and its new subsidiaries, but also affected the appraisal of local government achievement as well as the central principle to build a 'harmonious society'. 
In 2012 the central state required the local government and SOE to end the payoff dispute immediately to avoid social disturbance. To facilitate resolution of disputes, local government sought help from NGOs to make assessments of environmental damage and to represent residents to negotiate with the SOE. Under increasing pressure from the central state to secure a 'harmonious society', local government and the local SOE accepted liability to make payoffs to local residents. Although final payoffs were not universally satisfactory, it was a significant step in the struggle against the local rare-earth industry. The different actors described their various motivations on this:

\footnotetext{
Although there were also some differences between the amount we required and the final compensation, we were glad for the NGOs' mediation and receiving the payoff we sought. (RES1)
}

We saw this [NGO mediation] as the quickest way to solve the dispute, as it had a negative impact on maintaining social stability. (LGOV3)

The dispute resolution helped us to verify the industrial consolidation valid for bettering CSR. (COM5)

The central state also need the successful resolution of payoff, in order to implement its harmonious society project at a local level. (NGO3)

It was a great opportunity for us to improve the relationship with local authorities. (NGO1)

As a result, it seems all actors involved were happy with this result. However, it has only been a temporary fix for securing the state's hegemony in re-organizing China's environmental governance. To date, the local residents have not yet received the amount they originally asked for to cover their losses over the past 20 years. Equally, the local government and SOE only made a temporary concession, facing the central state's pressure, and the NGOs still need to negotiate with the different levels of government institutions to define their precise roles.

Green-rebalancing. Since the early 2000s, two departments were established in local government to maintain a balance between economic growth and sustainable development. Department One emphasizes economic development, while Department Two focuses on environmental protection. However, within the second transition eras we identified, the reinforced corporatist ties used to hinder government support for Department Two's decision-making. A government officer justified the importance of Department Three facing the increasing pressure for green-rebalancing: 
An 'implicit conflict', in which Department One usually has the advantage over Department Two due to traditional thinking that 'economic success is the success of local governance', hinders cooperation to approach sustainable development... [thus], in 2011, our department [Department Three] was established for internal control, promoting internal collaboration for greenrebalancing the rare-earth industry. (LGOV3)

Since 2011, any new planning by Departments One or Two must be reported to Department Three for approval. The pivotal moment for Department Three came in 2012's environmental assessment of the local SOE, when national environmental performance criteria developed by the MEP were adapted to international standards of the extractive industry. Department Three was engaged in administrative coordination to provide support for Department Two's and the SOE's environmental rectification plans. Since 2012, there has been a big improvement in the SOE's green performance in terms of emission control and waste treatment as well as releasing environmental monitoring and CSR reports.

In 2015, the strictest new environmental requirement in China, the 'New Environmental Protection Law' was formally released, with more stringent requirements on corporate environmental performance and environmental policy implementation as well as more emphasis on the civil society participation in environmental monitoring. Within this new era, green re-balancing has been one of the most important hegemony building processes to approach effective environmental governance in China. Green NGO activism has gradually become an efficient way to effect the transformative top-down change in the nascent sustainable development in China's passive revolution. With the deepening of passive revolution, green NGOs may play the role of a more equal partner with government agencies and corporations in environmental governance and be more effective in publicizing their environmental concerns with fewer administrative restrictions.

\section{Theorizing China's passive revolution}

Our analysis shows that the dynamic hegemony building processes in the development of China's environmental governance have mainly been driven from the top, in terms of the evolving top-down organizational processes of the state from centralizing to reappraising then to the recent green re-balancing. Gramsci has termed this 'passive revolution' which, according to Levy et al. (2016, p. 370), entails 'complex processes of mutual adjustment and accommodation'. Therefore, drawing on 30 years of empirical data of one of the most important strategic assets in China - the rare-earth industry - our study has investigated the dynamic and contested governance interactions, and changes over time, between five main actors in China's top-down passive revolution though which the hegemonic elites, in our case the central state, have given up some of their power to prevent a real revolution from taking place. 
We identified three evolving eras for the changes of hegemony building processes and their corresponding aggregated dimensions: from top-down growth hegemony during the mass production era before the 2000s, to reorganizing hegemony during the transition era between the early 2000s and 2012, and then to today's nascent green growth hegemony (see Figure 2).

Facing increasing supranational challenges, market-oriented reform requirements, and bottom-up pressures on reorganizing the rare-earth industry, the state has gradually relaxed its politico-economic control to reorganize hegemony and accommodate challenges in China's passive revolution. Based on the extent of disruption of hegemony and the efficiency of environmental governance, we developed Figure 3 to foreshadow the processes of passive revolution, challenges and accommodation in organizing the environmental governance of China's rare-earth industry over the past 30 years.

Figure 3. China's passive revolution since 1990.

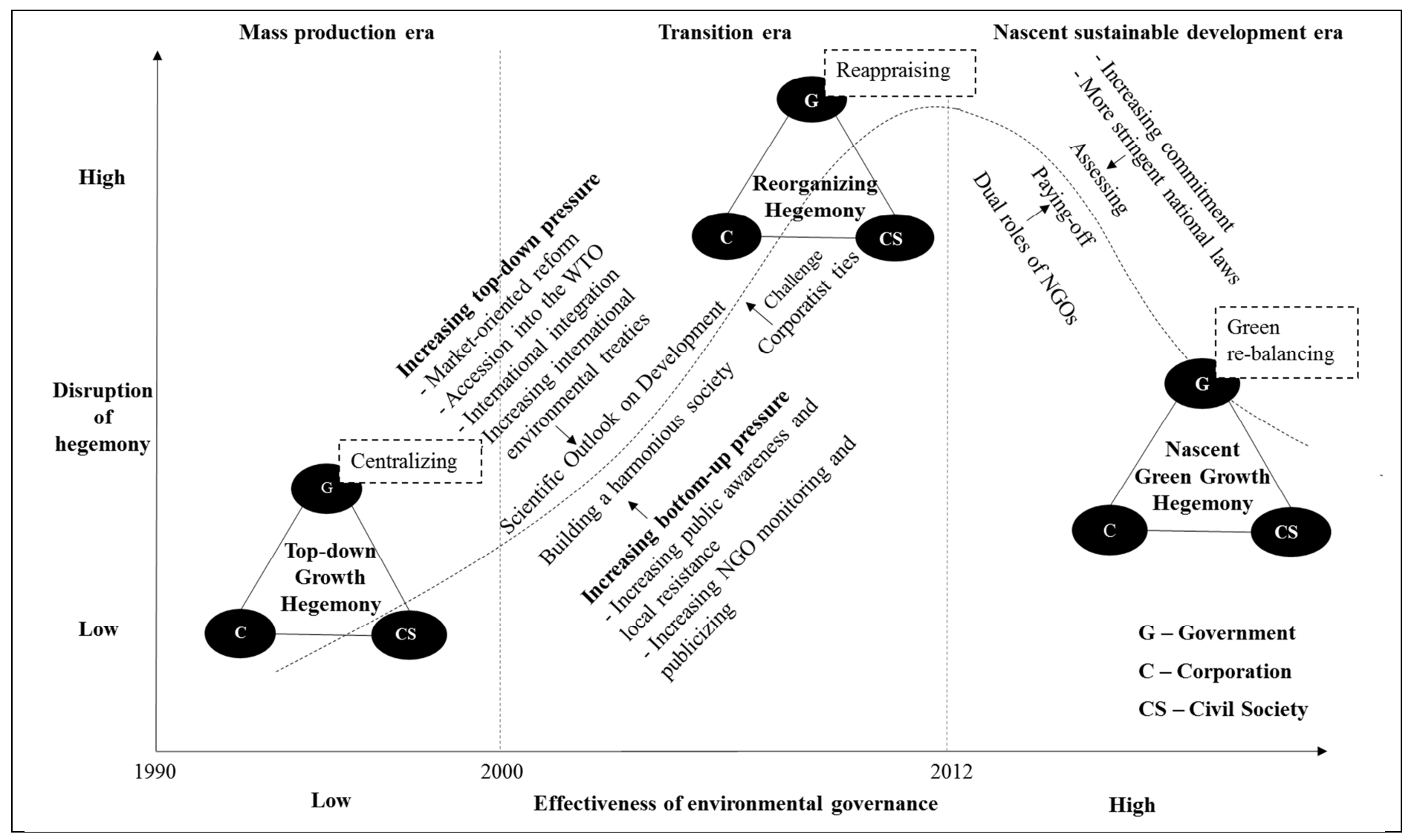

\section{Top-down growth hegemony in mass production era}

After a long period of planned economy in China, the state continued with its top-down growth hegemony during the mass production era of the 1990s. Centralized commands aimed at maximizing rare-earth material output, increasingly 
for export purposes. This effort was exercised through 'the state and juridical government' (Gramsci, 1971, p. 12). Our interviewees confirmed that the local government strictly followed the centralized decision-making and supported the local SOE for output maximization. At the same time, the local government took responsibility for the local SOE's business operation and sheltered its production activities from environmental pressures. In the early 1990s, there was not much local resistance; people needed China's rapid industrialization and economic growth to satisfy their basic needs, they thus deferred to the state's top-down growth hegemony.

Our first order codes and second order themes pointed to what has been called a centralized approach to economic control. During the 1990s' hegemony building, the state still held strong hegemonic capacity to acquire the business and civil society actors' consent to its central planning, thus, shown as the first era of Figure 3, the disruption of hegemony is low.

However, near the end of the 1990s domestic environmental awareness had gradually been triggered by the increasing economic and political 'integration of China in the world' (Mol \& Carter, 2006, p. 163). The concepts of 'sustainable development, green technology and corporate environmentalism' had slowly been introduced to China (Child et al., 2007, p. 1023). The centralized growth hegemony was hence gradually challenged by a wide range of factors, as detailed by our data: emergence of a national market economy; deepening of international integration and openness to global economy and polity; increased commitments to international environmental treaties; more stringent national environmental laws and regulations; growing public environmental awareness; increasing local environmental complaints and contests; and new inclusion of NGOs in hegemony building (see also Mol \& Carter, 2006). Thus, in Figure 3 we could see that there was an increasing disruption for the hegemony of China's environmental governance since the mid-1990s. With the increasing requirement to enlarge the social base of the state as well as the increasing demands of international negotiations for multilateral environmental agreements (Child et al., 2007; Mol \& Carter, 2006), the top-down growth hegemony in China's mass production era eventually crumbled.

\section{Reorganizing hegemony in transition era}

Since the early 2000s, facing up to increasing environmental challenges and pressures at home and abroad, the traditional top-down growth hegemony had been challenged by a wide range of factors. Thus, there was a continuing increase of the disruption of hegemony along with growing environmental protests, as shown in Figure 3 . In order to mitigate the increasing hegemonic disruption and avoid a real revolution, the state has emphasized the construction of an environmentally friendly 'harmonious society' and granted greater material concessions to civil society actors in the form of better social policies and environmental politics. For example, the 'Scientific Outlook on Development' was 
developed, to harmonize the environmental and economic perspectives of national development strategies (see also Hui, 2017; Mol and Carter, 2006; Xue et al., 2007).

As Gray (2010) reminds us, China's transformation - alongside 'the implosion of non-capitalist systems in Eastern Europe and the former Soviet Union' (Morton, 2010, p.325) - must also been seen in a global context that has seen 'capitalism expanding from its core to the periphery'. China's reorganization of its governance of the rare-earth industry must therefore be seen as part of its inclusion in the global division of labour and capitalist productive relations. This inclusion into the global trade system was cemented when China joined the WTO in 2001, which has had the side effect of certain minimum environmental standards being pushed onto its political economy. As a supranational pressure, membership of the WTO has enhanced the importance of international norms and standards in domestic business interactions in China (Mol \& Carter, 2006). The central state started to establish an effective and integral environmental governance system via a top-down industrial consolidation of the rare-earth industry. However, below the central state there are 'local government administrations' at the municipal and provincial level (Child \& Lu, 1990, p. 323), which acted as challengers during the process of passive revolution. Conflicts were hence inevitable when the state raised the environmental performance criteria, requiring the local SOE to be engaged in green upgrade. Therefore, at the local level, the transition era was a difficult period in terms of reconciling the opposing interests and aims to maximize economic and environmental benefits simultaneously' (Banerjee, 2003, p. 158), due to the corporatism we identified.

Interorganizational dependence is particularly manifested in closely-regulated industries with high strategic value (Xing \& Shaw, 2013). On the one hand, the local government relies on the economic performance of local SOEs to fulfil both financial and political goals (Shi et al., 2014). On the other hand, the local government also needs to supervise local the SOE's green performance, ensuring national emission standards can be achieved. Most neoGramscian studies on environmental governance in the OS field (e.g. Levy \& Spicer, 2013; Nyberg et al., 2013; Rothenberg \& Levy, 2012) emphasize that corporations, despite their direct involvement in energy wastage, resource depletion and pollution of various kinds, play a significant role in environmental governance and private regulatory approaches to implement and negotiate environmental policies. In our case study, however, during this transition era the corporatist ties reinforced between local government and SOE may have hindered the re-organization process of environmental governance spearheaded by the central state. Without strict administrative enforcement measures, for example the 2012 environmental assessment, it would be difficult for the rare-earth industry to be a socially responsible and accountable business in China's nascent sustainable development.

With the political and market-oriented transition, China's growing openness to the global market increased international influence on reorganizing a new environmental governance regime as 'a new organizational field', involving a wide range of interest groups, such as government agencies, competing corporations, NGOs and 
communities (Child et al., 2007, p. 1013). With increasing environmental awareness in Chinese civil society, the state also had to accommodate pressures from below. Most neo-Gramscian writings in OS view grassroots NGOs and social movements as autonomous groups challenging the power and environmental performance of corporations and the state (e.g. Levy \& Egan, 2003; Levy \& Newell, 2005; MacKay \& Munro, 2012). NGOs in China, under the 'dual administration system', have been much less successful, autonomous and antagonistic in political negotiations and contestations than those in Western countries (Hofman et al., 2017). However, although 'a more party-state controlled form of civil society organization is visible in China' (ibid., p. 662), as our data shows, NGOs started to play a dual role as both supporting and challenging hegemony, envisaged by Gramsci (1971). Thus, civil society's contribution to China's nascent environmental reform was manifested in two ways: the formation of unwritten social norms to be respected by the state authorities and 'the rise of critical environmental coverage' (Mol \& Carter, 2006, p. 160).

Therefore, we identified an aggregate dimension of China's hegemony in this transition era of 'reorganizing hegemony'. Figure 3 shows that the disruption of hegemony in China's passive revolution continued to increase from the mid-1990s. In order to mitigate the hegemonic disruption risk, the environmentally friendly 'harmonious society' project has been launched to sustain the long-term domination of the state through securing the consent of business and civil society actors. The state started to reappraise its governance policies of this strategically important industry, with the primary focus shifting from output and profit maximization to sustainable development. However, the central state's environmental policies were adjusted - and to some extent jeopardized - by the local government in order to meet the regional development needs that are largely focused on economic growth. More specifically, the corporatist ties reinforced in the transition era limited the effectiveness of local environmental protection administrations. Therefore, the disagreements about exactly how the rare-earth industry can be made greener continued between central and local government agencies, and the dynamic of societal expectations of mining sector's green re-balancing also continued to be mediated by the state.

\section{Green growth hegemony in nascent sustainable development era}

In the transition era, as demonstrated in our case, many contradictions emerged, such as conflicts between different levels of governments, payoff disputes between business and residents, struggles of NGOs with governmental agencies and corporate malpractices. In order to counteract such conflicts and regain control, the recent Xi Jinping government continues to place emphasis on 'harmonious society' (Hui, 2017), elevating the importance of sustainable development (Zhang et al., 2016). With the central state's increased commitment to achieving the sustainable development of the traditionally heavily-polluting industries, China has advanced 'the actual amount of environmental information disclosed to civil society actors' and 'the diversification and pluralism of environmental information suppliers and 
users' (ibid., p. 17). This has resulted in what has been called 'informational environmental governance' (ibid., p. 24; Zhan \& Tang, 2013), making local environmental information more transparent than ever to the five different actors.

As a result, reorganizing hegemony in the transition era has gradually given way to a nascent green growth hegemony, driven by the state, to mobilize the alignment of interests among different actors in constructing an environmentally friendly 'harmonious society', mitigating the disruption of hegemony in China's passive revolution. As shown in Figure 3, the hegemonic disruption - driven by the environmental contestations between our case's five actors - culminated in the 2012 environmental assessment exercise.

Responding to the increasing pressure from the state and growing payoff requests from the locals, the local government and SOE admitted liability for the environmental problems created over the past ten years. To avoid a further wave of widespread social disturbances, the local government took the lead in appropriating funds to make payoffs to local residents. This is in line with Viveros (2014) who reports on mining corporations providing economic compensation for damage done to local communities so as to fulfill their CSR obligations. Our data shows paying-off and green updating helped the SOE secure business interest and the local government achieve social stability, mitigating the disruption of state hegemony.

In this 'greening' process, the roles of environmental NGOs as both environmental monitor and conflict mediator have been insightful with a gradual relaxation of government control. While in existing neo-Gramscian studies in OS NGOs are often portrayed as bottom-up challengers (e.g. Levy \& Spicer, 2013; Nyberg et al., 2013), our data confirms Gramsci's conception of the dual role of civil society, 'as semi-autonomous arenas of cultural and ideological struggle, and also as key allies in securing hegemonic stability' (Levy \& Newell, 2005, p. 54). In our case, the local green NGOs organized a press conference in 2006 to expose the serious environmental pollution, which could be regarded as the 'fuse' of intensifying environmental contestations in organizing the rare-earth industry. MacKay and Munro (2012) also emphasize the increased tactical advantages of mass and alternative media to win the climate change debate. After the conflicts cemented in 2012, the NGOs mediated payoff disputes for many years. Paying off the residents, as an important step to implement the 'harmonious society' project at a local level, has cemented the hegemony building. Although NGOs in China seem to exercise less influence on corporate environmental decision-making, their activism has expanded as 'a deliberate party-state functional approach toward putting pressure on firms that severely pollute' (Hofman et al., 2017, p. 662). Such understanding of the dual role of NGOs in both contesting and supporting state power extends the neo-Gramscian conception of civil society to the unique context of China's top-down passive revolution.

However, in the nascent hegemonic arrangement of sustainable development in China, 'green growth' for constructing an environmentally friendly 'harmonious society' might be just a temporary fix for re-balancing coercion 
and consent between the state and non-state actors. For example, local residents often feel that they have not been compensated adequately and NGOs' mediation role, often arranged by the local authorities, may further be challenged by the locals. As pointed out by Zhan \& Tang (2013, p. 385) and also hinted at by our case study, 'Chinese NGOs could begin to take advantage of conflicts between the central and local governments, and those between local governments and local residents.' In our case, NGOs exposed the local environmental issues to attract the central state's attention. With increasing top-down pressure on the local government and SOE, NGOs started to mediate local disputes and make recommendations for compensation. With the further expansion of public participation channels such as mass media and the Internet (ibid.), civil society actors in China will put increasing pressure on the nascent green growth hegemony in China. The macro-level contestation between economic growth and environmental protection and the organizational dynamics in building a 'harmonious society' will continue in the further hegemony building processes of achieving sustainable development in China.

\section{Conclusion}

To conclude this article, we summarize the four main contributions we make to the OS literature. Our main empirical contribution has been to analyze the dynamic interactions and contestations between government agencies, business and civil society in organizing the environmental governance of China's rare-earth industry. This industry is of vital importance for the emerging global 'green economy', and is of strategic importance for many industrialized countries around the world (Wübbeke, 2013). However, the uneven geological distribution of rare-earth ores concentrates the global rare-earth industry in only a few countries, including China, Australia, the US, Brazil, and India (Hayes-Labruto et al., 2013). The strategic importance of the rare-earth industry - and its very dirty track record - makes it almost impossible to study empirically. Our study, with an in-depth understanding of hegemony building processes in the development of environmental governance of China's rare-earth industry, is hence unique and an important contribution in its own right, bridging this empirical gap in OS and the wider social sciences. It also provides empirical insight into the way environmental governance is organized in China, a politico-economic context that is often neglected in Western-centric neo-Gramscian studies in the OS field. We provide rare empirical insight into the contestations amongst state, corporate and civil society actors, and particularly our discussion of NGO activism in China is a first in OS.

With such an empirical focus, the neo-Gramscian framework is utilized to provide a dynamic understanding of evolving hegemony building processes among different actors in China's top-down passive revolution. Compared with more conventional stakeholder theories (e.g. Dawkins \& Lewis, 2003) and political CSR frameworks (e.g. Scherer \& 
Palazzo, 2011), the neo-Gramscian approach provides a more historical and dynamic understanding of the changing power relations in the process of hegemony building (see Levy \& Spicer, 2013; Morton, 2010); a subtler understanding of the role of civil society in organizational interactions with state and business (see Spicer \& Böhm, 2007; MacKay \& Munro, 2012); and a more sophisticated understanding of processes of challenging and accommodating (see Arnold \& Hess, 2017). With increasingly pluralistic yet contested roles of government agencies, corporations and civil society actors in re-organizing China's rare-earth industry, the neo-Gramscian perspective highlights the need to center the analysis on multiple actors, investigating the diversity of micro-level organizational processes in the hegemony building processes of China's passive revolution.

Theoretically, this article makes three contributions. First, we provide a particular focus on the re-regulation and reconfiguration of state power in contemporary alliance building, which has arguably been de-emphasized or neglected by neo-Gramscian authors in OS, who have arguably overemphasized the power of private actors, such as corporations and NGOs, in environmental governance situated in Western contexts (see e.g. Girei, 2016; Levy \& Scully, 2007; MacKay \& Munro, 2012; McGuirk et al., 2014; Nyberg et al., 2013). Within 'a form of state-manipulated market economy' (Harvey, 2005, p. 122), our case analysis has enriched our understanding of the role of the state and made visible the unique characteristics of what can be called China's passive revolution from above, which has implications for interrogating other non-Western processes of alliance building (Child \& Lu, 1990; Child et al., 2007; Jiang \& Hall, 1996). In sum, our understanding of the institutional changes of the state has unpacked the specific and concrete relations that make up the state and its dynamic interactions with other non-state actors in the Chinese hegemony building processes.

Second, we have provided a distinct organizational perspective on China's 'passive revolution' by identifying three evolving eras of hegemony building that are constituted of different organizational processes. This Gramscian conception provides a subtler understanding of how state agencies 'accommodate pressure from challengers' in hegemony building (Levy \& Spicer, 2013, p. 670). Most existing neo-Gramscian scholarship in OS has looked at 'bottom-up' contestations in contemporary institutional formations in Anglo-Saxon contexts. For example, Levy et al. (2016) understand the political dynamics of CSR as a Gramscian process of passive revolution, which is resembled by dynamic interactions between NGOs and business. Within China's state-dominated governance regime, our study has highlighted the 'top-down' changes and hegemonic contestations driven from above (Gray, 2010; Li \& Christensen, 2012; Xing \& Shaw, 2013). More specifically, the changes have been mainly driven by the central state in the hegemony building of China's environmental protection system (Child \& Lu, 1996; Child et al., 2007). We also identify how the state has given up certain power to accommodate and internalize the increasing environmental pressures from external supra-national actors and civil society at home, in order to prevent a real revolution. According to Harvey 
(2005, p. 151), China is moving towards 'neoliberalization and the reconstitution of class power, albeit with distinctly Chinese characteristics'. We hence conclude that the empirical realities of China's passive revolution may necessitate a different approach to understanding neo-Gramscian hegemony building, one that takes the role of the state and its contestations with other actors more seriously than exemplified by current neo-Gramscian thinkers in OS. Therefore, we provide a unique and dynamic understanding of contemporary China's hegemonic coalitions, shifting from the outdated 'top-down growth hegemony' to a process of 'reorganizing hegemony', leading most recently to a 'nascent green growth hegemony'. Without doubt this process of hegemony building has not come to an end, as the latest arrangement should be seen as a temporary fix to secure the state's hegemony in organizing China's environmental governance regime. The dynamics and hegemonic struggles between the state and non-state actors will continue as China continue on its path of, what we have identified as, passive revolution.

Third, according to the conception of the dual role of civil society supporting and challenging hegemony in the Gramscian approach (Levy \& Newell, 2005), the article has provided a novel insight into the dual role of NGOs in China's passive revolution. We identified how NGOs have accommodated government administrations in China's passive revolution: on the one hand, representing grievances of civil society, helping vulnerable groups, disclosing and reporting local malpractices to contest hegemony; on the other hand, mediating local disputes and making recommendations for compensation to cement hegemony. We expect green NGOs to continue to challenge the status quo via different channels of the mass and alternative media, further unsettling but also confirming the state's role as hegemonic elite actor.

Having said this, we believe that our innovative research would benefit from further comparative studies on the institutional diversity of environmental governance in a broader variety of non-Western countries. Moreover, the dynamic understanding of the role of the state and its interactions with other societal actors in China's passive revolution would also be meaningful for future research in other so-called emerging economies, such as other BRICS countries - Brazil, Russia, India and South Africa - which may have similar politico-economic governance systems to China.

\section{References}

Abrahamsen, R. (1997). The victory of popular forces or passive revolution? A neo-Gramscian perspective on democratisation. The Journal of Modern African Studies, 35, 129-152.

Arnold, D., \& Hess, M. (2017). Governmentalizing Gramsci: Topologies of power and passive revolution in Cambodia's garment production network. Environment and Planning A, 49, 2183-2202. 
Böhm, S., Misoczky, M. C., \& Moog, S. (2012). Greening capitalism? A Marxist critique of carbon markets. Organization Studies, 33, 1617-1638.

Böhm, S., Spicer, A., \& Fleming, P. (2008). Infra-political dimensions of resistance to international business: A neoGramscian approach. Scandinavian Journal of Management, 24, 169-182.

Banerjee, S. B. (2003). Who sustains whose development? Sustainable development and the reinvention of nature. Organization Studies, 24, 143-180.

Banerjee, S. B. (2012). A climate for change? Critical reflections on the Durban United Nations Climate Change Conference. Organization Studies, 33, 1761-1786.

Banerjee, S. B. (2017). Transnational power and translocal governance: The politics of corporate responsibility. Human Relations, first published 19 September 2017, doi: 10.1177/0018726717726586.

Bieler, A., \& Morton, A. D. (2004). A critical theory route to hegemony, world order and historical change: NeoGramscian perspectives in international relations. Capital \& Class, 28, 85-114.

Child, J., \& Lu, Y. (1990). Industrial decision-making under China’s reform, 1985-1988. Organization Studies, 11, 321351.

Child, J., Lu, Y., \& Tsai, T. (2007). Institutional entrepreneurship in building an environmental protection system for the People's Republic of China. Organization Studies, 28, 1013-1034.

Cox, R. (1981). Social forces, states and world orders: Beyond international relations theory. Journal of International Studies, 10, 126-155.

Crouch, C. (2006). Modeling the firm in its market and organizational environment: Methodologies for studying corporate social responsibility. Organization Studies, 27, 1533-1551.

Dawkins, J., \& Lewis, S. (2003). CSR in stakeholder expectations: And their implication for company strategy. Journal of Business Ethics, 44, 185-193.

De Bakker, F. G., Den Hond, F., King, B., \& Weber, K. (2013). Social movements, civil society and corporations: Taking stock and looking ahead. Organization Studies, 34, 573-593.

Djelic, M. L., \& Etchanchu, H. (2017). Contextualizing corporate political responsibilities: Neoliberal CSR in historical perspective. Journal of Business Ethics, 142(4), 641-661.

Eisenhardt, K. M. (1989). Building theories from case study research. The Academy of Management Review, 14, 532550.

Girei, E. (2016). NGOs, management and development: Harnessing counter-hegemonic possibilities. Organization Studies, 37, 193-212.

Gramsci, A. (1971). Selections from the prison notebooks. New York: International Publishers. 
Gramsci, A. (2007). Prison Notebooks, Volume III. Buttigieg, J. A. (Ed.). New York: Columbia University Press.

Gray, K. (2010). Labour and state in China's passive revolution. Capital \& Class, 34, 449-467.

Hall, P. A., \& Soskice, D. (Eds.) (2001). Varieties of capitalism: The institutional foundations of comparative advantage. Oxford: Oxford University Press.

Harvey, D. (2005). A brief history of neoliberalism. Oxford: Oxford University Press.

Hayes-Labruto, L., Schillebeeckx, S. J., Workman, M., \& Shah, N. (2013). Contrasting perspectives on China's rareearths policies: Reframing the debate through a stakeholder lens. Energy Policy, 63, 55-68.

Hofman, P. S., Moon, J., \& Wu, B. (2017). Corporate social responsibility under authoritarian capitalism: Dynamics and prospects of state-led and society-driven CSR. Business \& Society, 56, 651-671.

Hui, E. S. I. (2017). Putting the Chinese state in its place: A march from passive revolution to hegemony. Journal of Contemporary Asia, 47, 66-92.

Jessop, B. (2002). Liberalism, neoliberalism, and urban governance: A state-theoretical perspective. Antipode, 34, 452472.

Jessop, B. (2013). Revisiting the regulation approach: Critical reflections on the contradictions, dilemmas, fixes, and crisis dynamics of growth regimes. Capital \& Class, 37, 5-24.

Jiang, S. H., \& Hall, R. H. (1996). Local corporatism and rural enterprises in China's reform. Organization Studies, 17, 929-952.

Laclau, E., \& Mouffe, C. (2001). Hegemony and Socialist Strategy, London: Verso.

Levy, D. L. (2008). Political contestation in global production networks. The Academy of Management Review, 33, 943963.

Levy, D. L., \& Egan, D. (2003). A Neo-Gramscian approach to corporate political strategy: Conflict and accommodation in the climate change negotiations. Journal of Management Studies, 40, 803-829.

Levy, D. L., \& Newell, P. J. (Eds.) (2005). The business of global environmental governance. Cambridge, MA: MIT Press.

Levy, D. L., Reinecke, J., \& Manning, S. (2016). The political dynamics of sustainable coffee: Contested value regimes and the transformation of sustainability. Journal of Management Studies, 53, 364-401.

Levy, D. L., \& Scully, M. (2007). The institutional entrepreneur as modern prince: The strategic face of power in contested fields. Organization Studies, 28, 971-991.

Levy, D. L., \& Spicer, A. (2013). Contested imaginaries and the cultural political economy of climate change. Organization, 20, 659-678. 
Li, X., \& Christensen, S. F. (Eds.) (2012). The rise of China and the impact on semi-periphery and periphery countries. Aalborg-Denmark: Aalborg University Press.

MacKay, B., \& Munro, I. (2012). Information warfare and new organizational landscapes: An inquiry into the ExxonMobil-Greenpeace dispute over climate change. Organization Studies, 33, 1507-1536.

Maielli, G. (2015). Explaining organizational paths through the concept of hegemony: Evidence from the Italian car industry. Organization Studies, 36, 491-511.

McGuirk, P., Bulkeley, H., \& Dowling, R. (2014). Practices, programs and projects of urban carbon governance: Perspectives from the Australian city. Geoforum, 52, 137-147.

Mol, A. P. J., \& Carter, N. T. (2006). China's environmental governance in transition. Environmental Politics, 15, 149170.

Moran, T. (2010). China's strategy to secure natural resources: Risks, dangers and opportunities. Washington, DC: Peterson Institute for International Economics.

Morgan, G. (2011). Comparative capitalisms. International Studies of Management \& Organization, 41, 12-34.

Morton, A. D. (2010). The continuum of passive revolution. Capital and Class, 34, 315-342.

Nyberg, D., Spicer, A., \& Wright, C. (2013). Incorporating citizens: Corporate political engagement with climate change in Australia. Organization, 20, 433-453.

Okereke, C., Bulkeley, H., \& Schroeder, H. (2009). Conceptualizing climate change governance beyond the international regime. Global Environmental Politics, 9, 58-78.

Pearse, R. (2010). Making a market? Contestation and climate change. Journal of Australian Political Economy, 66, 166-198.

Reinecke, J., Manning, S., \& Von Hagen, O. (2012). The emergence of a standards market: Multiplicity of sustainability standards in the global coffee industry. Organization Studies, 33, 791-814.

Rhodes, R. A. W. (2007). Understanding governance: Ten years on. Organization Studies, 28, 1243-1264.

Rothenberg, S., \& Levy, D. L. (2012). Corporate perceptions of climate science: The role of corporate environmental scientists. Business \& Society, 51, 31-61.

Sassoon, A. S. (2001). Globalization, hegemony and passive revolution. New Political Economy, 6, 5-17.

Scherer, A. G., \& Palazzo, G. (2011). The new political role of business in a globalized world: A review of a new perspective on CSR and its implications for the firm, governance, and democracy. Journal of Management Studies, 48(4), 899-931.

Shi, W. L., Markóczy, L., \& Stan, C. V. (2014). The continuing importance of political ties in China. The Academy of Management Perspectives, 28, 57-75. 
Schrempf-Stirling, J. (2016). State power: Rethinking the role of the state in political corporate social responsibility. Journal of Business Ethics, 1-14.

Spaargaren, G., \& Mol, A. P. (1992). Sociology, environment, and modernity: Ecological modernization as a theory of social change. Society \& Natural Resources, 5(4), 323-344.

Spicer, A., \& Böhm, S. (2007). Moving management: Theorizing struggles against the hegemony of management. Organization Studies, 28, 1667-1698.

Van Bommel, K., \& Spicer, A. (2011). Hail the snail: Hegemonic struggles in the slow food movement. Organization Studies, 32, 1717-1744.

Viveros, H. (2014). Examining stakeholders' perceptions of mining impacts and corporate social responsibility. Corporate Social Responsibility and Environmental Management, 23, 50-64.

Wübbeke, J. (2013). Rare-earth elements in China: Policies and narratives of reinventing an industry. Resources Policy, $38,384-394$.

Wittneben, B. B. F., Okereke, C., Banerjee, S. B., \& Levy, D. L. (2012). Climate change and the emergence of new organizational landscapes. Organization Studies, 33, 1431-1450.

Xing, L., \& Shaw, T. M. (2013). The political economy of Chinese state capitalism. Journal of China and International Relations, 1, 88-113.

Xue, L., Simonis, U. E., \& Dudek, D. J. (2007). Environmental Governance for China: Major recommendations of a task force. Environmental Politics, 16, 669-676.

Zhang, L., Mol, A. P. J., and He, G. (2016). Transparency and information disclosure in China's environmental governance. Current Opinion in Environmental Sustainability, 18, 17-24.

Zhan X., \& Tang S. Y. (2013) Political opportunities resource constraints and policy advocacy of environmental NGOs in China. Public Administration, 91, 381-399. 